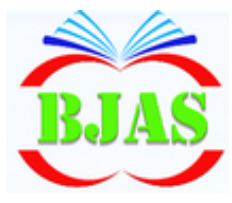

ISSN $1814-5868$
Available online at http://bajas.edu.iq https://doi.org/10.37077/25200860.2019.273 College of Agriculture, University of Basrah
Basrah Journal of Agricultural Sciences

\title{
Effect of Humic Acid on Some growth Characteristics and Green Yield of Two Hybrids of Broad bean (Vicia faba L.) \\ Hajar A. Abdel Nabi \& Abbas K. Obaid*
}

\author{
Department of Horticulture and Garden Landscape, College of Agriculture, University of Basrah, \\ Iraq \\ *Corresponding authore-mail: abbaskadium@gmail.com
}

Received 19 September 2019; Accepted 18 November 2019; Available online 22 November 2019

\begin{abstract}
The experiment was conducted at the agricultural research station of the College of Agriculture- University of Basrah in 2018-2019 season in sandy loam soils in order to study the effect of three concentrations of humic acid $\left(0,2\right.$ and 4 g.L $\left.\mathrm{L}^{-1}\right)$ on the growth and yields of two hybrids of Broad bean ("Rico and Rama F1"). Split Plot Design by Randomized Complete Block Design (R.C.B.D) with three replications, and the least significant difference test (L.S.D) was used to compare averages at a probability level of 0.05 . The most important results obtained are: The hybrid "Rico" is gave a significant increase in the number of branches.Plant ${ }^{-1}$, the percentage of flowering in addition to the average weight of the pod, while the hybrid "Rama F1" gave a significant increase in the number of flowers and pods.Plant ${ }^{-1}$, weigh of pod.Plant ${ }^{-1}(259.3 \mathrm{gm})$ in addition to the total yield $\left(24.34\right.$ tons.ha $\left.^{-1}\right)$. Humic acid concentrations 2 and 4 g. $\mathrm{L}^{-1}$ gave a significant increase in number of leaves.plant ${ }^{-1}$, leaf area, soft weight of vegetative, number of flowers.plant ${ }^{-1}$, number of pods.plant ${ }^{-1}$, average weight of pod, yield. Plant ${ }^{-1}(259.9 \mathrm{~g})$ in addition the total yield (24.40 tons.ha ${ }^{-1}$ ), while control treatment gave a significant increase in the percentage of ripening flowers. The interaction between humic acid and hybrids had significant increase in all characters in the study except the percentage of ripening flowers.
\end{abstract}

Key words: Vicia faba L., Humic acid, Hybrids, Green pods.

\section{Introduction}

Plant broad bean (Vicia faba L.) a winter annual considers an Important yield of a plant of the legume family (Fabaceae). It's the third most important legume plant after soybeans and peas (Singh et al., 2013). Broad bean cultivated for green pods, dry and soft seeds are used in cooking because they are highly nutritious and important because their seeds contain a high protein content of about 25$40 \%$ of dry weight (Al-Asawi, \& Kharbit, 2011), and a good source of many nutrients such as $\mathrm{K}, \mathrm{Ca}, \mathrm{Mg}$ and $\mathrm{Fe}$ (Lizarazo et al.,
2015; Longobardi et al., 2015), as well as every $100 \mathrm{~g}$ of green seed content $72.1 \mathrm{~g}$ water, $17.8 \mathrm{~g}$ total carbohydrates, $2.2 \mathrm{~g}$ fiber, $0.4 \mathrm{~g}$ fat, $1.1 \mathrm{~g}$ ash, $37 \mathrm{mg}$ iron, plus vitamins A, B1, B2, and C (Hassan, 2002). In addition, the seeds also contain many biologically active compounds such as polyphenols (Turco et al., 2016) and carotenoids (Neme et al., 2015).

The statistics referred that the production world of broad bean reached 4.46 million tons, China was superior in world production with 1.61 million tons (FAO STAT, 2017). 
Recent studies are geared towards increasing production efficiency through experimenting with the cultivation of good genotypes with high productivity and good quality appropriate to the conditions of agriculture areas. A study was carried out of twenty broad bean varieties by Gurmessa (2018) in Ethiopia, found the four varieties ("Obse, Gachana, Ashange and Dedia") had significant increase in the length of the pod, the number of pods.plant ${ }^{-1}$, the number of seeds.pod ${ }^{-1}$, the weight of 100 Seed as well seed yield.

In addition, natural and organic materials can be used as Soil amendments, including humic materials. Humic acid is one of the most economical commercial products and is fast and harmless to humans, animals and plants (Anonymous, 2005). In addition, humic acid improves soil fertility and increases nutrient readiness as well as improving or reducing the negative effect of saline stress (El-Hefny, 2010). There are many studies in the use of humic acid compounds in improving plant growth and yield. Ayman et al. (2009) in study as four concentrations of humic acid (0, 1000, 2000 and $\left.3000 \mathrm{mg} . \mathrm{L}^{-1}\right)$ on broad bean plants (Giza 3 cultivar) found that $2000 \mathrm{ml} . \mathrm{L}^{-1}$ gave a significant increase in plant height, number of branches, number of leaves, soft weight of vegetative, the number and weight of the pods as well the number of seeds.

This study was conducted with the aim of investigating the effect of humic acid on growth and yield of broad bean hybrids.

\section{Materials \& Methods}

The experiment was carried out during 20182019 in Agriculture Reasarch station, College of Agriculture, University of Basrah in sandy loam soils in order to study the effect of three concentrations of humic acid (0,2 and 4 g.L${ }^{1}$ ) on the growth and yields of two hybrids of broad bean ("Rico and Rama F1". Factorial experiment within Randomized Complete Block Design (R.C.B.D.). Split Split-Plot Design with three replications, the hybrids was considered the main factor (Main-Plot) and the addition of humic acid secondary factor (Sub-Plots) to include 18 experimental units, and the least significant difference test (L.S.D) was used to compare averages at a probability level of 0.05 (Al- Rawi \& Khalaf Allah, 1980).

The land was divided into three sections for each section of two ridges with $25 \mathrm{~m}$ length and $75 \mathrm{~cm}$ between ridges. Broad bean seeds were soaked in water for 24 hours and planted on two sides of the ridges at $25 \mathrm{~cm}$ between on 18 October 2018. After 35 days of germination addtion humic acid were done and after 15 days later the second and third addition was done.

The following measurements were taken for five plants from each experimental unit: plant height $(\mathrm{cm})$, number of leaves. plant ${ }^{-1}$, leaf area, plant ${ }^{-1}\left(\mathrm{~cm}^{2}\right)$, is calculated according to the weight method (Watson and Watson ,1953). number of branches. Plant ${ }^{-1}$, soft weight of vegetative $(\mathrm{g})$, number of flowers and pods.Plant ${ }^{-1}$, percentage of ripening flowers, weigh of pod.Plant ${ }^{-1}$, yield. Plant ${ }^{-1}(\mathrm{~g})$ in addition the total yield $\left(\mathrm{ha}^{-1}\right)$.

\section{Results \& Discussion}

Table (1) showed that no significant effect of humic acid in plant heigh and number of branches, while 2 and 4 g.L. $\mathrm{L}^{-1}$ concentrations gave a significant higher in number of leaves and leaf area compared to the distilled water, while $4 \mathrm{gm} . \mathrm{L}^{-1}$ concentration exceeded in the fresh weight of the vegetative, and the concentration of $2 \mathrm{gm} . \mathrm{L}^{-1}$ had no significant 
effect with the other two concentrations. The hybrid "Rico" gave a significant increase in the number of branches.Plant ${ }^{-1}$, exceeded "Rama F1", while the hybrids had not gave any significant effect on height of the plant, number of leaves, leaf area in addition the soft weight of the total vegetation. The interaction between "Rico" hybrid with a concentration 2 g. $\mathrm{L}^{-1}$ humic acid gave a significant in height of plant reached $72.7 \mathrm{~cm}$ and the same hybrid with the concentration 4 g.L ${ }^{-1}$ exceeded in number of leaves (242.9 leaves), leaf area $\left(17014 \mathrm{~cm}^{2}\right)$, number of branches.plant ${ }^{-1}$ (10.20 branches), compared to lowest height $(62.5 \mathrm{~cm})$, number of leaves (189.6 leaves) and leaf area $\left(11840 \mathrm{~cm}^{2}\right)$ resulted in the "Rama F1 " hybrid with 0 g.L. $\mathrm{L}^{-1}$ humic acid, and the lowest number of branches was 9.13 branches produced in "Rama F1 " hybrid with $4 \mathrm{~g}$, The hybrid "Rama F1" with 4 g.L $\mathrm{L}^{-1}$ gave a significant increase in total weight of the vegetative $(467.9 \mathrm{~g})$ compared to $370.4 \mathrm{~g}$ produced in the same hybrid interaction with 0 g.L $\mathrm{L}^{-1}$ humic acid.

Table (1): The effect of humic acid on Some growth Characteristics of two hybrids of broad bean.

\begin{tabular}{|c|c|c|c|c|c|c|}
\hline \multicolumn{2}{|c|}{$\begin{array}{c}\text { Treatment } \\
\text { and } \\
\text { Concentration }\end{array}$} & $\begin{array}{l}\text { Plant } \\
\text { height } \\
(\mathrm{cm})\end{array}$ & $\begin{array}{l}\text { Leaves } \\
\text { number }\end{array}$ & $\begin{array}{l}\text { Leaf } \\
\text { Area } \\
\left(\mathrm{cm}^{2}\right)\end{array}$ & $\begin{array}{c}\text { stem } \\
\text { number. } \\
\text { Plant }^{-1}\end{array}$ & $\begin{array}{c}\text { Fresh vegetative } \\
\text { weight the }\end{array}$ \\
\hline \multirow{3}{*}{$\begin{array}{l}\text { Humic acid } \\
\text { gm. } l^{-1}\end{array}$} & 0 & 63.9 & 172.1 & 4705 & 9.43 & 377.6 \\
\hline & 2 & 70.7 & 205.7 & 5817 & 9.57 & 405.0 \\
\hline & 4 & 70.3 & 212.7 & 5478 & 9.67 & 464.6 \\
\hline \multicolumn{2}{|c|}{ L.S.D 0.05} & N.S & 7.88 & 523.6 & N.S & 41.18 \\
\hline \multirow[b]{2}{*}{ Hybrids } & Rico & 69.5 & 203.3 & 5761 & 9.78 & 412.2 \\
\hline & $\begin{array}{c}\text { Rama } \\
\text { F1 }\end{array}$ & 67.1 & 190.4 & 4906 & 9.33 & 419.3 \\
\hline \multicolumn{2}{|c|}{ L.S.D 0.05} & N.S & N.S & 351.1 & 0.38 & N.S \\
\hline \multirow{3}{*}{ Rico } & 0 & 65.4 & 168.6 & 4497 & 9.47 & 384.7 \\
\hline & 2 & 72.7 & 208.1 & 6570 & 9.67 & 390.5 \\
\hline & 4 & 70.3 & 233.1 & 6215 & 10.20 & 461.4 \\
\hline \multirow{3}{*}{ Rama F1 } & 0 & 62.5 & 175.7 & 4914 & 9.40 & 370.4 \\
\hline & 2 & 68.6 & 203.3 & 5064 & 9.47 & 419.6 \\
\hline & 4 & 70.3 & 192.3 & 4742 & 9.13 & 467.9 \\
\hline \multicolumn{2}{|c|}{ L.S.D 0.05} & 7.84 & 12.45 & 618.4 & 0.81 & 58.01 \\
\hline
\end{tabular}

Table (2) showed that a significant effect of humic acid and hybrids in all the traits of the product under experiment, the 2 and 4 g.L ${ }^{-1}$ concentrations gave a significant increase in number of flowers.Plant ${ }^{-1}$ (67.17 and 71.12 flowers), number of pods.Plant ${ }^{-1}$ (13.79 and 13.51 pods), average weight of the pod (19.02 and $19.24 \mathrm{~g}$ ), yield per plant (261.8 and 259.9 g) and total yields (24.40 and 24.57 ton.ha ${ }^{-1}$ ), respectively, while 0 g. $\mathrm{L}^{-1}$ humic acid treatment significantly exceeded in the percentage of ripening flowers $(21.71 \%)$. As for the hybrids, the hybrid "Rama F1" exceeded "Rico" significantly in the number 
of flowers. Plant ${ }^{-1}$ (70.81 flowers), number of pods.Plant $^{-1}$ (14.14 pods), yield per plant $(259.3 \mathrm{~g})$ and total yields (24.34 ton.ha $\left.{ }^{-1}\right)$. "Rico" gave a significant increase in percentage of ripening flowers $(20.82 \%)$ and average pod weight (18.99 $\mathrm{g})$.

The interaction between both factors was significant in all traits except Percentage of flowering contract, The hybrid "Rama F1" treated at $4 \mathrm{gm} . \mathrm{L}^{-1}$ humic acid were significantly higher in number of flowers.Plant ${ }^{-1}$ (75.92 flowers), yield per plant (269.4 g) and total yields (25.29 ton.ha' ${ }^{1}$ ), while the hybrid plants "Rama F1" treated with concentration $2 \mathrm{gm}^{-1}$ in the number of pods.Plant ${ }^{-1}$ (14.53 pods) compared to the hybrid plants "Rico" with not treatment with humic acid that gave less values in the number of flowers (57.00), number of pods.plant ${ }^{-1}$ (12.00), yield per plant (221.3 gm) and total yields (20.77 ton.ha $\left.{ }^{-1}\right)$, while the hybrid plants "Rico" interaction with 2 g. $\mathrm{L}^{-1}$ humic acid significantly higher in the average weight of the pod (19.76 g) compared to 17.35 gm produced in hybrid plants "Rama F1" not treated with humic acid, showed that the interaction of humic acid and hybrids had not a significant effect in the percentage of ripening flowers.

This increase may be attributed to the positive effect of the nutrients present in humic acid on plant growth by increasing the permeability of cell membranes, stimulating enzymatic reactions, cell division, cell elongation, increasing production of plant enzymes, and stimulating intracellular vitamins (Pettit, 2003) which helped stimulate absorption of existing nutrients in the soil (Arancon et al., 2006). which helped increase vegetative growth which reflected on flowering and yield. These results are consistent with those of Ayman et al. (2009) and Shafeek et al. (2013).

Table (2): The effect of humic acid on green yield of of two hybrids of broad bean.

\begin{tabular}{|c|c|c|c|c|c|c|}
\hline \multicolumn{2}{|c|}{$\begin{array}{c}\text { Treatment } \\
\text { and } \\
\text { Concentration }\end{array}$} & $\begin{array}{c}\text { Flowers } \\
\text { Number. } \\
\text { Plant }^{-1}\end{array}$ & $\begin{array}{l}\text { Pods } \\
\text { Number. } \\
\text { Plant }^{-1}\end{array}$ & $\begin{array}{c}\text { pod } \\
\text { Weight } \\
\text { (g) }\end{array}$ & $\begin{array}{l}\text { Yield per } \\
\text { plant } \\
(\mathrm{g})\end{array}$ & $\begin{array}{c}\text { Total } \\
\text { yields } \\
\left.\text { (ton.ha }{ }^{-1}\right)\end{array}$ \\
\hline \multirow[b]{3}{*}{$\begin{array}{c}\text { Humic acid } \\
\text { gm. } .^{-1}\end{array}$} & 0 & 60.33 & 10.08 & 14.69 & 148.1 & 10.43 \\
\hline & 2 & 67.17 & 10.61 & 16.02 & 170.0 & 11.97 \\
\hline & 4 & 71.12 & 10.89 & 16.24 & 176.9 & 12.45 \\
\hline \multicolumn{2}{|c|}{ L.S.D 0.05} & 4.88 & 0.46 & 0.61 & 11.49 & 0.81 \\
\hline \multirow[b]{2}{*}{ Hybrids } & Rico & 61.61 & 9.81 & 15.96 & 156.6 & 11.02 \\
\hline & $\begin{array}{c}\text { Rama } \\
\text { F1 }\end{array}$ & 70.81 & 11.31 & 15.34 & 173.5 & 12.21 \\
\hline \multicolumn{2}{|c|}{ L.S.D 0.05} & 3.29 & 0.57 & 0.13 & 7.90 & 0.56 \\
\hline \multirow[b]{3}{*}{ Rico } & 0 & 57.00 & 9.20 & 15.04 & 138.3 & 9.74 \\
\hline & 2 & 61.50 & 10.05 & 16.76 & 168.5 & 11.86 \\
\hline & 4 & 66.33 & 10.13 & 16.07 & 162.8 & 11.46 \\
\hline \multirow[b]{3}{*}{ Rama F1 } & 0 & 63.67 & 11.00 & 14.35 & 157.9 & 11.12 \\
\hline & 2 & 72.83 & 11.22 & 15.28 & 171.5 & 12.07 \\
\hline & 4 & 75.92 & 11.63 & 16.41 & 190.9 & 13.44 \\
\hline \multicolumn{2}{|c|}{ L.S.D 0.05} & 5.74 & 0.59 & 0.71 & 13.59 & 0.96 \\
\hline
\end{tabular}




\section{Conclusions}

Broad bean can be grown better in saline soil when added soil with humic acid fertilizers, in which Broad bean plants were shown vigorous vegetative growth (leaf number and leaf area) and yields (Yield plant, Total yields) compared to control.

\section{Acknowledgements}

We wish to thank all people who help me to complete the experience.

\section{References}

Al-Asawi, Y.J.A. \& Kharbit, H.K. (2011). The effect of zinc feeding on the yield and its constituents for the pea. J. Iraqi Agric. Sci., 42(2): 20-30. .(In Arabic).

Al-Rawi, K.M. \& Khalaf Allah, A.A.M. (1980). Design and analysis of agricultural experiments. Dar Al-Kutub for Printing and Publishing, Mosul: 448pp. (In Arabic).

Anonymous (2005). Humic acid, organic plant food and root growth promoters. An earth friendly company (Eco- chem.). File : G. (cited from Jasim, A.H. \& Hadi, K. F. (2017). Effect of silicon, GA3 and humic acid on broad bean plants growth. Euphrates J. Agric. Sci. 9(4): 86-96. (In Arabic).

Arancon, N.Q.; Edwards, C.A.; Lee, S. \& Byrne, R. (2006). Effects of humic acids from vermicomposts on plant growth. European J. Soil Biol., 42: S65-S69.

Ayman, M.; El-Ghamry, A.M.; Abd El-Hai, K.M. \& Ghoneem, K.M. (2009). Amino and humic acids promote growth, yield and disease resistance of faba bean cultivated in Clayey soil. Aus. J. Basic Appl. Sci., 3(2): 731-739.

El-Hefny, E.M. (2010). Effect of saline irrigation water and humic cid application on growth and productivity of two cultivars of cowpea (Vigna unguiculata L. Walp). Aus. J. Basic Appl. Sci., 4(12): 6154- 6168.

FAO STAT. (2017). Production stat: crops. FAO statistical databases (FAO stat), food and agriculture organization of the United Nations (FAO), http://faostat.fao.org.

Gurmessa, L.D. (2018). Performance of Faba Bean (Vicia faba L.) Varieties Grown Under Broomrapes (Orobanche spp.) Infestation in South Tigray, Ethiopia. M. Sc. Thesis, Univ. Harmaya: 70pp.

Hassan, A.A. (2002). Production of legume vegetables, Arab Publishing House, Cairo: 424pp. (In Arabic).

Lizarazo, C.I.; Lampi, A.M.; Sontag-Strohm, T.; Liu, J.; Piironen, V. \& Stoddard, F.L. (2015). Nutritive quality and protein production from grain legumes in a boreal climate. J. Sci. Food Agric., 95: 20532064. doi: 10.1002/jsfa.6920.

Longobardi, F.; Sacco, D.; Casiello, G.; Ventrella, A. \& Sacco, A. (2015). Chemical profile of the carpino broad bean by conventional and innovative physicochemical analyses. J. Food Qual. 38: 273-284. doi: 10.1111/jfq.12143.

Neme, K.; Bultosa, G. \& Bussa, N. (2015). Nutrient and functional properties of composite flours processed from pregelatinised barley, sprouted faba bean and carrot flours. Int. J. Food Sci. Technol., 50: 2375-2382. doi: 10.1111/ijfs. 12903.

Pettit, R.E. (2003). Organic matter, humus, humates, humic acid, fulvic acid and humin: Their importance in soil fertility and plant health. https://humates.com/pdf/ORGANICMATT ERPettit.pdf. 
Shafeek, M.R., Helmy, Y.I. ; Nadia, M. O. \& Rizk F. A. (2013). Effect of foliar fertilizer with nutritional compound and humic acid on growth and yield of broad bean plants under sandy soil conditions. J. App. Sci. Res., 9(6): 3674-3680.

Singh, A.K.; Bharati, R.C.; Manibhushan, N.C. \& Pedpati, A. (2013). An assessment of faba bean (Vicia faba L.) current status and future prospect. Afr. J. Agric. Res., 8(55): 6634- 6641.

Turco, I.; Ferretti, G. \& Bacchetti, T. (2016). Review of the health benefits of faba bean (Vicia faba L.) polyphenols. J. Food Nutr. Res., 55: 283-293.

Watson, D.J. \& Watson, A.M. (1953). Comparative physiological studies on the growth of field crops III. Effect of infraction with (Beet yellow). Ann. Appl. Bio., 40: 1-18. 